\title{
PERLAWANAN MASYARAKAT MINORITAS DALAM PERENCANAAN PEMBANGUNAN PERKOTAAN
}

\author{
Rahman Malik \\ Program Studi Magister Sosiologi, Fakultas Ilmu Sosial dan Politik, \\ Universitas Sebelas Maret \\ rahmanmalik20592@gmail.com
}

\begin{abstract}
The purpose of this research is to see how the resistance of minority comunities toward the silencing of their right by the government of Malang City to contribute the development planning in Malang city. According to this case it is related to public policy which is formed on the basis of collective thinking between the government and the people of Malang City as a whole. This research method is qualitative with a study approach case. The informants in this study were taken from several ranks of the community management of the Persatuan Tuna Netra Indonesia(PERTUNI) of Malang City. The data collection techniques of this study used interviews and observation. The data analysis technique used in this study is the pattern matching K.Yin. The findings of this study are related to the resistance of minority communities to the government of Malang city due to the limited rights of minorities in the planning of builders in Malang including: (1) holding a peaceful speech on the anniversary of disability. (2) carrying out advocacy efforts at the Malang City Regional Representative Council (DPRD) office. (3) Actively involved in providing education for persons with disabilities in Malang City who have difficulty accessing public facilities. (4) conducting social criticism and evaluation studies through social media related to difficult access in using public facilities for persons with disabilities.
\end{abstract}

Keywords: minority comunities, disablity, Pertuni, public policy, public facilities

\begin{abstract}
Abstrak
Penelitian ini bertujuan untuk melihat bagaimana perlawanan masyarakat minoritas atas dibungkamnya hak-hak mereka oleh pemerintah kota Malang untuk berkontribusi dalam perencanaan pembangunan di Kota Malang. Dalam hal ini terkait dengan kebijakan publikyang
\end{abstract}


dibentuk atas dasar pemikiran kolektif antara pemerinta dan masyarakat Kota Malang secara keseluruhan. Metode penelitian ini yaitu kualitatif dengan pendekatan studi kasus. Informan dalam penelitian ini diambil dari beberapa jajaran kepengurusan komunitas Persatuan Tuna Netra Indonesia (PERTUNI) Kota Malang. Adapun teknik pengumpulan data penelitian ini menggunakan wawancara dan observasi. Teknik analisis data yang digunakan dalam penelitian ini menggunakan penjodohan pola K.Yin. Adapun hasil temuan penelitian ini terkait dengan perlawanan masyarakat minoritas terhadap pemerintah kota Malang akibat terbatasnya hak kaum minoritas di dalam perencanaan pembangun di Kota Malang diantaranya: (1) mengadakan orasi damai pada hari peringatan disabilitas. (2) melakukan upaya advokasi di kantor Dewan Perwakilan Rakyat Daerah (DPRD) Kota Malang. (3) Terlibat aktif memberikan edukasi penyandang disabilitas Kota Malang yang mengalami kesulitan mengakses fasilitas publik. (4) melakukan kritik sosial dan studi evaluasi melalui media sosial terkait dengan akses yang sulit dalam menggunakan fasilitas publik bagi penyandang disabilitas.

Kata Kunci: masyarakat minoritas, difabel, Pertuni, kebijakan publik, fasilitas publik

\section{PENDAHULUAN}

Era sekarang kehidupan di masyarakat perkotaan lebih bersifat heterogen, yang mana masyarakat yang berada di suatu kota tidak lagi di dominasi oleh masyarakat yang berasal dari tempat asal,suku,ras yang sama. Melainkan masyarakat di perkotaan banyak yang berasal dari tempat yang berbeda, suku yang berbeda, ras yang berbeda, dangan bermacam-macam latar belakang dan profesi. Masyarakat kota merupakan masyarakat yang kebanyakan dari anggota-anggotanya terdiri dari manusia yang bermacam-macam lapisan dan tingkatan masyarakat yang berbedabeda, pendidikan, kebudayaan, dan lainlain. Mayoritas masyarakat perkotaan hidup dengan berbagai macam profesi yang bersifat non agraris. Sikap hidupnya cenderung individualisme atau egoisme,yang mana masing-masing anggota masyarakatnya berusaha untuk hidup sendiri-sendiri tanpa terkait oleh anggota masyarakat yang lainnya.

Kehidupan masyarakat perkotaan diatur oleh dalam sebuah struktur yang disebut dengan peraturan daerah.
Sebuah peraturah daerah yang dibentuk pemerintahan di perkotaan harus memilikikemampuanuntuk menjalankan roda pemerintahan dengan menimbang segala aspirasi masyarakat, memenuhi segala kebutuhan masyararakat sesuai regulasi serta menjamin hak-hak warga negara yang hidup pada daerah tersebut. Namun di era sekarang faktanya tujuan dan prinsip itu tak lebih dari sebuah ilusi dan metafora semata. Seringkali prinsip dan tujuan itu tidak dapat di implementasikan dengan baik oleh pemerintah untuk masyarakat dengan sebaik mungkin. Masih seringnya pemerintah yang bersikap apatis terhadap aspirasi masyarakat terutama masyarakat menengah kebawah terkait tata kelola pembangunan di perkotaan. Hal ini menimbulkan sebuah permasalahan baru yang melibatkan konflik kolektif antara masyarakat dan pemerintah daerah. Sehingga, demokratisasi yang lewat menembus berbagai wilayah, tak jarang lengah dari berbagai kepentingan warga negara, terutama bagi mereka yang terpinggirkan (Thohari, 2014). 
Dampak dari adanya dualisme yang melibatkan pemerintah daerah dan masyarakat di perkotaan itu sendiri. Tentunya hal ini akan merambat kepada kebijakan-kebijakan pemerintah daerah yang memunculkan perspektif yang terkesan pilih kasih dan lebih mementingkan kaum borjuis atau kaum kelas atas di perkotaan. Akibatnya berdampak kepada kebijakan-kebijakan pemerintah yang sangat menguntungkan dan terkesan memanjakan kaum kelas atas di perkotaan. Tetapi, di sisi yang berbeda kebijakan tersebut bagaikan kontradiksi dan begitu terasa nyata dan memberatkan bagi masyarakat kalangan bawah di perkotaan terutama masyarakat marginal dan masyarakat pingguran perkotaan. Praktek kesenjangan dan pilih kasih yang dilakukan pemerintah daerah untuk masyarakat tertentu, ini berbahaya dan dapat menimbulkan pergerakan revolusi atas gejolak ketidakpuasan masyarakat kaum urban menengah kebawah dalam hal menuntut hak mereka untuk bisa berpartisipasi dalam membangun kotanya. menyebabkan terjadi pergejolakan masyarakat kelas bawah.

Dapatdilihatdarikebijakan-kebijakan pemerintah yang berhubungan dengan fasilitas publik. Sejatinya fasilitas publik ini dibuat untuk dipergunakan bagi seluruh masyarakat yang tinggal di suatu kota tersebut. Setiap masyarakat berhak untuk mempergunakan fasilitas-fasilitas publik tersebut tanpa adanya larangan atau teguran dalam mempergunakannya. Tetapi pada faktanya sekarang, banyak ditemukan fasilitas publik dan kebijakankebijakan publik yang dibuat pemerintah lebih menguntungkan kelas-kelas sosial masyarakat kelas atas. Sehingga ini akan menjadi tembok tinggi bagi kelompok- kelompok minoritas seperti kelompok difabel. Fenomena itu secara tidak langsung akan membentuk pola pusaran yang mana kelompok minoritas dianggap sebagai kaum marginal dan dianggap sebagai sampah perkotaan. Kaum minoritas di perkotaan tak dianggap lagi sebagai bagian dari masyarakat kota dan cenderung sebagai kaum yang dapat merusak keindahan kota tersebut yang memang diciptakan untuk memanjakan masyarakat lapisan sosial kelas atas.

Fenomena yang dijelaskan diatas mengenai banyaknya kebijakan pemerintah daerah terkait fasilitas publik yang dirumuskan pemerintah yang tidak aksesibilitas terhadap kaum minoritas seperti kaum difabel ini dapat kita lihat apa yang terjadi di Kota Malang. Seperti yang diketahui bahwa, Kota Malang sendiri pada tahun 2013 ditetapkan oleh dinas pendidikan dan kebudayaan sebagai kota ramah terhadap kaum minoritas terlebih-lebih kaum difabel. Hal ini dapat dilihat dari beberapa pengharhgaan yang diberikan dinas pendidikan dan kebudayaan terhadap kota Malang. Pertama kota pendidikan yang inklusif dan ramah bagi para penyandang difabel. Kedua di kota Malang mempunyai kampus yang merupakan pelopor pendidikan inklusif di perguruan tinggi, akan menjadi paradoks jika Kota Malang tidak ramah terhadap para penyandang difabel. Ketiga Malang merupakan kota terbesar di Jawa Timur setelah Kota Surabaya. Di Kota ini tingkat populasi para penyandang difabel cukup tinggi dibandingkan dengan kota-kota lainnya di Jawa Timur (Thohari, 2014).

Berkaca dari fenomena di atas, maka penelitian ini bermaksud untuk melihat bagaimana upaya perlawanan 
gerakan sosial masyarakat minoritas di Kota Malang, Jawa Timur dalam hal ini masyarakat difabel Persatuan Tuna Netra (PERTUNI) dalam menuntut hak mereka atas kota dalam perencanaan pembangunan di Kota Malang. Dalam membedah kasus ini akan digunakan perspektif Hak Manusia Atas Kota yang dikemukakan oleh Henry Lefebvre.

\section{METODE PENELITIAN}

Penelitian ini dilakukan pada tahun 2018 di Komunitas Lingkar Sosial (LINKSOS) di Kota Malang, Jawa Timur. Metode yang digunakan di dalam penelitian ini adalah kualitatif dengan pendekatan studi kasus. Model penelitian ini yang dibatasi oleh waktu, aktivitas dan pengumpulan detail informasi dengan menggunakan berbagai prosedur pengumpulan data selama waktu tersebut (Cresswel, 1994). Teknik pengambilan data dilakukan dengan cara wawancara secara mendalam dengan beberapa informan yang berasal dari jajaran struktur kepengurusan komunitas difabel Persatuan Tuna Netra Indonesia (PERTUNI) Kota Malang. Penentuan informan ini tentunya sesuai dengan karektiristik informan dan observasi yang dilakukan disekitar lokasi penelitian. Teknik analisis data yang digunakan adalah penjodohan pola (Yin, 2009). Serta teknik keabsahan data menggunakan teknik validasi responden dengan metode cross check.

\section{HASIL DAN \\ PEMBAHASAN}

Melihat dari fenomena penelitian ini, menjadi menarik ketika melihat bagaimana peranan masyarakat minoritas terlebih lagi para penyandang difabel di Kota Malang yang seringkali mengalami kesulitan dalam menikmati fasilitas publik yang ada di Kota Malang. Salah satunya adalah masyarakat minoritas penyandang difabel yang tergabung di dalam komunitas Persatuan Tuna Netra Indonesia (PERTUNI) Kota Malang. Banyaknya para penyandang difabel yang mengeluh ketika mereka kesulitan di dalam memanfaatkan akses publik seperti rambu-rambu lalu lintas khusus difabel, jalur pejalan kaki khusus difabel, dan toilet khusus difabel. Makanya tak sedikit dari mereka para penyandang difabel di komunitas Persatuan Tuna Netra(PERTUNI) melakukan perlawanan terhadap pemerintah kota Malang dengan menuntut dan mengkritik bahkan melakukan tindakan perlawanan kepada pemerintah kota Malang.

Hal ini tersebut tentunya disebabkan oleh adanya akibat dari ketidakpuasan mereka dalam mendapatkan akses fasilitas publik sebagaimana mestinya. Dalam hal ini terkhususnya lagi fasilitas publik yang diperuntukkan bagi para penyandang difabel yang dirasa masih banyak memiliki kekurangan bahkan mendapatkan perhatian yang minim. Ini akibat dari pemerintah yang berperilaku neoliberalis yang lebih memanjakan kaum masyarakat urban kelas atas di Kota Malang. Sehingga hak-hak atas kota kaum minoritas seperti kaum difabel tidak lagi mendapat perhatian bagi pemerintah kota Malang.

Usaha-usaha perlawanan yang dilakukan oleh komunitas Persatuan Tuna Netra Indonesia (PERTUNI) yang ada di Kota Malang dalam menuntut hak mereka atas pembangunan di Kota Malang antara lain adalah: (1) mengadakan orasi damai pada hari peringatan disabilitas internasional pada saat acara Car Free Day berlangsung di 
Jalan Ijen Kota Malang; (2) melakukan upaya advokasi jejak pendapat dan dengar pendapat ke kantor DPRD Kota Malang; (3) Terlibat aktif untuk memberikan edukasi para penyandang disabilitas yang mengalami kesulitan dalam mengakses fasilitas publik di Kota Malang; (4) melakukan kritik sosial dan studi evaluasi melalui media-media sosial terkait dengan akses yang sulit dalam menggunakan fasilitas publik bagi penyandang disabilitas Persatuan Tuna Netra Indonesia (PERTUNI) dan masyarakat difabel kota Malang pada umumnya.

Munculnya upaya-upaya perlawanan dalam bentuk gerakan sosial lebih disebabkan adanya pergejolakan yang menuntut perbaikan kebijakan dengan melibatkan hak-hak kaum difabel dalam merumuskan segala kebijakan-kebijakan yang menyangkut kemaslahatan masyarakat kota Malang. Gerakan sosial tersebut memiliki tujuan agar hak-hak para penyandang difabel di Kota Malang dapat memanfaatkan akses publik dengan mudah. Fenomena yang terjadi ini sebenarnya sebuah fenomena sosial di sebuah masyarakat perkotaan yang menuntut adanya keadilan masyarakat.

Menjadi menarik fenomena perlawanan masyarakat difabel yang diposisikan sebagai kaum minoritas di Kota Malang dalam melawan dan mengkritik pemerintah kota Malang dan kebijakan-kebijakannya melalui konsep yang telah dirumuskan oleh Henri Lefebvre tentang "Hak atas Kota”. Menurutnya, hak atas kota ini merupakan sebuah kebebasan individu untuk dapat mengakses sumberdaya-sumberdaya yang dimiliki suatu kota. Hak atas kota itu adalah hak yang dimiliki warga kota itu sendiri untuk dapat mengubah penguhuni kota dan wajah kota itu sendiri.

Bagi Lefebvre (Sungranyes dan Mathiviet, 2010) hak manusia atas kota merupakan suatu bentuk nyata, yang hadir dengan segala kerumitannya untuk kemudian dapat ditransformasikan dan diperbaharui kota tersebut sesuai dengan konteksekonomipolitikyangberkembang sesuai dengan situasi terkini. Pengertian tersebut, maka hak manusia atas kota tidak lagi dimaknai bahwa masyarakat minoritas berhak dalam mendapatkan akses pendidikan dan kesehatan gratis lagi, tetapi juga masyarakat minoritas juga memiliki hak untuk terlibat di dalam mentransformasikan dan memperbaharui kotanya. Pada intinya, masyarakat minoritas dalam hal ini masyarakat difabel termasuk yang berada di dalam komunitas Persatuan Tuna Netra Indonesia (PERTUNI) Kota Malang bukan lagi sebagai pelaku pasif di dalam sebuah kota, tetapi mereka harus di dorong menjadi pelaku yang aktif terlibat di dalam melakukan tindakan-tindakan transformasi dalam memperbaharui kotanya dalam hal ini adalah terlibat di dalam merancang pembangunan Kota Malang melalui kebijakan-kebijakan publik yang ramah dan akses tidak hanya bagi masyarakat normal dan kalangan atas, tetapi juga ramah dan akses bagi masyarakat minoritas dan kalangan masyarakat difabel di Kota Malang. terlebih lagi pada kebijakan-kebijakan publik yang berhubungan fasilitas publik yang sampai saat ini seringkali dikeluhkan oleh masyarakat difabel di Kota Malang dikarenakan tidak begitu ramah dan akses bagi penyandang difabel di Kota Malang.

Perlawanan yang dilakukan masyarakat minoritas dalam hal 
masyarakat difabel di Komunitas Persatuan Tuna Netra Indonesia (PERTUNI) kota Malang terhadap pemerintahkotaMalangmerupakansuatu disfungsi hubungan antara pemerintah daerah dengan masyarakatnya sendiri. Dimana pemerintah Kota Malang memainkan perannya secara sepihak dengan pihak-pihak neoliberalis dan konglomerasi yang melahirkan beberapa kebijakan-kebijakan publik yang lebih menguntungkan dan memanjakan beberapa pihak tertentu saja tanpa memikirkan masyarakat lainnya yang tinggal di Kota Malang seperti kaumkaum masyarakat menengah kebawah dan kaum minoritas di Kota Malang.

Padahal sejatinya, menurut David Harvey (2012), menjelaskan bahwa hak manusia atas kota tidak hanya sebuah insiatif atau kerja individu atau beberapa kelompok, melainkan merupakan sebuah insiatif dan kerja kolektif dari rakyat/ masyarakat secara keseluruhan. Dalam kasus ini, menjadi kontradiksi dengan penjelasan Harvey dan Lefebvre yang lebih menjelaskan peran masyarakat kolektif tanpa pandang kelas dalam membangun kotanya. Maka sebab itulah timbul beberapa bentuk perlawanan masyarakat minoritas kaum difabel di Kota Malang sebagai bentuk upaya masyarakat minoritas merespon ketidakpuasan mereka terhadap kebijakan-kebijakan publik pemerintah kota Malang yang cenderung memihak kaum kelas atas di kota Malang dan cenderung merugikan kaum minoritas di Kota Malang.

\section{KESIMPULAN}

Berdasarkan penelitian yang telah dilakukan, peneliti dapat menarik kesimpulan pada penelitian ini. Adapun kesimpulannya ditemukan beberapa bentuk perlawanan yang muncul dari masyarakat minoritas di Kota Malang dalamhalinimasyarakatdifabelPersatuan Tuna Netra Indonesia (PERTUNI) kota Malang terhadap pemerintah Kota Malang. Beberapa bentuk perlawanan yang dilakukan masyarakat minoritas di Kota Malang merupakan suatu bentuk respon ketidakpuasan mereka akan hakhak dan aspirasi masyarakat minoritas terlebih lagi para penyandang difabel yang terpasung oleh pemerintah kota Malang untuk terlibat aktif di dalam membangun Kota Malang melalui kebijakan-kebijakan publik yang dibuat secara kolektif. Sehingga dari fenomena tersebut menghasilkan praktek kebijakankebijakan publik pemerintah Kota Malang yang cenderung merugikan kaum minoritas dan lebih menguntungkan beberapa pihak konglomerasi dan masyarakat kelas menengah keatas di Kota Malang.

\section{DAFTAR PUSTAKA}

Ana Sungranyes, Charlotte Mathiviet (ed). 2010. Cities For All Proposals and Experiences Towards the Right to the City. Habitat International Coalitions.

Creswell, John H, 1994. Research Design: Qualitativeand Quantitative Approaches. London: Sage Publication.

Harvey, David. 2009. A Brief History of Neoliberalism. Oxford University Press.

Thohari, Slamet. 2014. Pandangan Disabilitas dan Aksesibilitas Fasiltas Publik bagi Penyandang Disabilitas di Kota Malang. Jurusan Sosiologi FISIP Universitas Brawijaya, Malang.

Yin, Robert K. 2009. Metode Studi Kasus. Jakarta: PT Rajagrasindo Persada. 